The Second Law of Thermodynamics.

Is it not true that the Second Law of Thermodynamics is contradicted by the known facts of diffusion? When, for instance, masses of hydrogen and nitrogen are separated by a palladium partition, a difference of pressure is set up, owing to the diffusion of some of the hydrogen into the compartment which at first contained only nitrogen. In this condition the system is able to do work at the expense of its own heat, or heat entering from without. The palladium, in fact, takes the place of Clerk Maxwell's Sorting Demon, though, in this case, the process cannot be made continuous.

Christ's College, Cambridge, November ig.

\section{BRITISH EXCAVATIONS IN THE NEAR} EAST, I904-5.

DRING the past year British archæologists have carried on the work of disinterring the remains of the ancient civilisations of Greece, Egypt, and Mesopotamia with energy. The excavations of the Trustees of the British Museum at Ephesus have resulted in interesting discoveries. The work was intended to supplement and complete that carried out under the auspices of the Trustees from forty to thirty years ago on the site of the Great Temple of Diana of the Ephesians. That work, carried out by the late Mr. J. T. Wood, resulted in the planning of the temple and the removal to England of many valuable antiquities now in the British Museum. The present work was entrusted by the trustees to the distinguished archæologist Mr. D. G. Hogarth. It has resulted in the discovery, undreamt of by Wood, of the remains of two earlier temples below that of the Crosus temple, which he supposed to be the earliest, and of a vast number of votive objects of the eighth and seventh centuries B.c., among them many of gold and silver, besides Egyptian blue composition scarabs of the early twenty-sixth dynasty period. These were found underneath the second or "præ-Crœsus" temple. By the laws of Turkey, the antiquities, especially those of precious metal, must go to the Museum of Constantinople, but duplicates will come to the British Museum. Much new knowledge of the third or Crosus temple, discovered by Wood, has also been gained. The two earlier ones seem to have been of interesting construction. Much heavy pumping work had to be carried out in the temple area, which had become filled with water. Mr. Hogarth is to be congratulated on having brought this interesting work to a successful conclusion.

On the mainland of Greece, Lakonia has been handed over by the Greek Government to the British School of Athens for excavations. Several minor discoveries of interest have been made, including that of a fifth-century local heroön, or hero-shrine, with its equipment of cultus-images, reliefs, figurines, and votive cups, \&c., near Monemvasia. The work was carried out by Mr. R. C. Bosanquet, the Director of the School, and Mr. F. C. Hasluck.

The Cretan work of the British School has now been brought to a conclusion. The excavation of the site of Palaikastro, in the province of Sitia, has not yet been completed, but is suspended, let us hope not for long. Mr. R. McG. Dawkins was in charge, and carried out his work most successfully under adverse conditions, owing to the now unhappily renewed troubles in the island, due to the fixed determination (whether it be right or wrong) of the Cretan people to effect their union with Greece. We can, parenthetically, only pray that Candia may not be the scene of riots, not for the sake of the Cretans, but for that of the museum, which contains all the trophies of the last few years' wonderful discoveries NO. I 883 , vOL. 73$]$ at Knossos and Phaistos, the destruction of whick would be an irreparable loss to the whole civilised world.

This by the way. Mr. Dawkins's work has resulted in the discovery of the complete stratification of the temple site back to the first post-Neolithic age, and the discovery of fine pottery of the various stages of the Minoan period. It is evident that the later temple was built over the Minoan settlement, probably as the result of a survival of religious tradition in connection with the site. The exploration of the Minoan town has been regularly continued. In the hills near by Mr. Dawkins also discovered a Neolithic settlement with a very interesting deposit of twenty stone axes, " more than half of them in brand-new condition. This discovery gives us, for the first time in the Egean, a definite idea of a Neolithic homestead."

The explorations of Messrs. Arthur Evans and Mackenzie at Knossos have been continued with the assistance of Mr. Doll as architect. By the kindness of Dr. Evans we are enabled to give a short sketch of the results of his work this season in advance. The chief work has been the exploration of the magazines on the paved way leading west from the "Stepped Theatral Area" (see Nature, October 5). More stores of tablets relating to the royal chariots and armoury have been found, and a complete building excavated. On the hillside beyond the Candia road, the building to which the way led from the palace has been found and partly excavated. It proved to be a late Minoan house, larger than any other dépendance of the palace, and in it were found the remains of a shrine containing fetish images in the shape of natural stalagmite blocks of quasi-human form, together with a painted clay goat and other figures. Owing to heavy rainfall, the modern wooden pillars of the quadruple staircase in the main palace gave way, and Dr. Evans was obliged to rebuild the whole. This he did in more solid form with stone pillars of ancient shape and appearance. More interesting discoveries were made during the course of the work. We regret to learn that owing to absence of outside support for the Cretan Exploration Fund the Knossian excavations may shortly be brought to an end. It is evident that an excavator cannot go on bearing indefinitely the greater part of the cost of his excavations himself, as Dr. Evans has done. There is much more of the greatest importance to science to be found at Knossos, and we again appeal to those who are interested to subscribe to the Cretan Exploration Fund. There ought to be some money somewhere for the most important archæological exploration of the decade, which, despite the claims of Egyptian excavations, Dr. Evans's work must undoubtedly be admitted to be. We hope and confidently expect that, after a pause of a year or two devoted to the full publication of the momentous results hitherto obtained, Dr. Evans will be enabled to proceed afresh with the exploration of Knossos.

In Egypt the chief excavations of the year have been those of the Egypt Exploration Fund. The excavators employed by the fund were, as before, Profs. Naville and Petrie, and Messrs. Hall, Currelly, and Ayrton, Mr. Hall being lent, as last year, by the British Museum. To Messrs. Naville, Hall, and Ayrton was assigned the continuance of the excavations at Dêr el-Bahari, with the assistance of $\mathrm{Mr}$. and Mrs. H. Garnett-Orme, who kindly gave their services to the Fund for this work. Messrs. Petrie and Currelly, with a party of helpers, among whom may be mentioned Captain Weill, of the French génie, were commissioned to investigate and clear 
the well known temple of Sarábit el-Khadim, in the Sinaitic peninsula. Captain Weill has made the Egyptian inscriptions of Mount Sinai his special study. The results of the first season's work on the eleventh dynasty temple at Dêr el-Bahari were described in Nature, June I6, I904; those of the second season have been equally interesting and important. The new temple is, in fact, the oldest now known at Thebes, and is the best preserved of the older temples of Egypt. It is the only temple of its period (about 2500 B.C.) known to us, and is therefore important as telling us previously unknown facts with regard to the architecture and art of that time. The temple is the funerary chapel of King Neb-hapet-Ra (formerly called "Neb-kheru-R ā") Mentuhetep, the first great Theban king. Last year's excavations were brought to an end when only a corner of the temple had been uncovered. Those of this year have resulted in the clearance of the main portion of it, leaving only the western end to be excavated this winter. It is a symmetrical rectangular building built upon an artificially leveiled platform of rock. In the centre is a square erection which was apparently the base of a dummy pyramid of small size. Round this is an ambulatory or corridor of octagonal pillars, the outer wall of which was decorated with coloured reliefs. The platform was approached from the east on its centre line by an inclined plane or ramp, flanked by colonnades of square pillars on the lower level. This arrangement of platform, ramp, and flanking colonnades was apparently copied by the later architects of the temple of Queen Hatasu or Hatshepsut close by, which was excavated for the Egypt Exploration Fund by Prof. Naville, assisted by Mr. D. G. Hogarth and others, some years ago. The main arrangement of the old temple, with its central pyramid, \&c., was not copied by Hatshepsut's architects.

A large number of fragments of the reliefs already mentioned have been found this year as last, and were exhibited at the annual exhibition of the Egypt Exploration Fund in the rooms of the Society of Biblical Archæology in July of this year. The brilliancy of their colouring and delicacy of their workmanship were remarkable, and they form an important addition to the chief known relics of Egyptian art. The carving of some of the sculptured hieroglyphs is of the finest style, which is not often seen in Europe, and was hardly known to many who had not visited Egypt and seen Abydos and Dêr el-Bahari.

Apart from the actual temple-buildings, the two most important discoveries were those of the sarcophagi of the priestesses of Hathor who were buried within the temple, and six portrait statues of the King Usertsen or Senusret III. of the twelfth dynasty, representing him at different periods of his life. The heads of two are missing. The portraits, especially the two oldest, are very fine. One of the white limestone sarcophagi is most beautifully carved with scenes of offerings being brought to the deceased priestess, of the cows of Hathor, \&c. The sarcophagus and one of the statues are illustrated in an article on the temple by $\mathrm{Mr}$. Hall in the August number of Man, from photographs taken by Mr. Ayrton.

The small votive offerings which were such a feature of last year's discoveries were not found in any quantity this year, but instead a much larger number of workmen's tools, hoes, baskets, mallets, $\& c_{.}$, were found.

Prof. Petrie's work consisted in the clearance and planning of Sarábit el-Khadim and the study of the Wadi Maghara inscriptions. In the IVadi Maghara an inscription of the early King Sa-nekht, whose tomb was discovered by Mr. Garstang at Bêt Khallâf, in Upper Egypt, a few years ago, was found. The peculiarities of the plan of Sarábit el-Khadim had long been known, and now that they have been fully made out they appear sufficiently curious to demand some explanation, which Prof. Petrie has attempted to give. He explains the building as not primarily an Egyptian but a Semitic shrine, with hanefiya courts like those of a mosque, while the peculiar stelæ inscribed with records of Egyptian miners and the upright stones, which are such a feature of the place, he identifies as Semitic bethels or baetyli. Prof. Petrie also claimed this as the only Semitic temple known. His conclusions do not, however, seem to be altogether approved by other archæologists, and Mr. R. C. Thompson, of the British Museum, has criticised them in a recent article in Man, to which Prof. Petrie has replied, with the result of drawing a further reply from $\mathrm{Mr}$. Thompson. The point about this being the only Semitic temple must undoubtedly be abandoned; the Babylonian temples are far older. That they are Sumerian is no argument against this, for the Semites took over most of their religious ideas from the Sumerians; but to an unprejudiced critic the weakest point of Prof. Petrie's argument seems to be the identification of the stelæ as bethels. If they were, they would, as Mr. Thompson says, be inscribed, not with mere records of Egyptian garrison and mining officials, with prayers to the Egyptian goddess Hathor, as they are, but with inscriptions of Semitic religious import, recording dreams and prophecies, \&c. Prof. Robertson Smith's "Religion of the Semites" should be consulted on this point. The form of the stelæ is as Egyptian and non-Semitic as their inscriptions; we may compare with them the stela or obelisk of Usertsen I. at Begig, in the Fayyum, and the two great stelæ in front of the funerary temple of King Sneferu at Mêdûm, discovered by Prof. Petrie himself in r $89 \mathrm{r}$.

A large number of interesting objects were brought back by the expedition, and were exhibited by the Egypt Exploration Fund at University College, Gower Street, in July.

Excavations have been carried on by Mr. Garstang for the University of Liverpool at Kom el-Ahmar, the site of the ancient Hierakonpolis, at Hissaya, south of Edfu, and at Esna. At Kom el-Ahmar Mr. Garstang found interesting remains of the third dynasty or earlier, at Hissaya graves of the Persian period, and at Esna a series of town-remains from Hyksos times until the twentieth dynasty. Two remarkable tomb-structures were found, of eight or ten chambers on the ground floor and a stairway leading up to the first floor, where there was a similar series. The site in general illustrated in an interesting fashion the provincial art of Egypt at the period. Excavation is to be resumed on it next year. We are indebted for these details to the kindness of Mr. Garstang.

In Mesopotamia the excavations of the British Museum at Kuyunjik, the site of Nineveh, have been brought to an end under the direction of $\mathrm{Mr}$. R. C. Thompson, after the departure of Mr. L. W. King. The excavations have resulted in the discovery of many interesting buildings previously unknown, including a temple of the god Nabu and a new palace of Sennacherib. The planning of the whole mound of Kuyunjik and its ruins has been carried out to its completion. Messrs. King and Thompson also visited the rock of Behistun or Bisutun in Persia, and re-copied the famous historical inscription of Darius, originally copied by Rawlinson. The text obtained by them will be the NO. I 883 , VOL. 73$]$ 
most complete and authoritative existing. Messrs. King and Thompson have also taken some unique photographs of the monument.

In the Sudan, Dr. Budge, of the British Museum, and $\mathrm{Mr}$. J. W. Crowfoot, Inspector of Education in the Sudan, have completed the work which the former began at Meroe in I903. They finally cleared out the shrine of the largest pyramid, and made some interesting explorations in the country near the Second Cataract. Dr. Budge, whose services had been previously lent to the Sudan Government by the British Museum in 1897,1899 , and 1903 , is now engaged on an account of his four missions to that country, which is announced to appear in the spring.

We cannot close this account of British archæoological work without a word of congratulation to our American friends on the success of the excavations of $\mathrm{Mr}$. Theodore N. Davis, assisted by $\mathrm{Mr}$. J. E. Quibell, the British Inspector of Antiquities in Upper Egypt, in the Valley of the Tombs of the Kings at Thebes. Mr. Davis found the untouched tomb of Iuaa and Tuaa, the father and mother of the great Queen Tyi, consort of Amenhetep III. and mother of the heretic King Akhunaten. The tomb was full of the most magnificent furniture, chariots, \&c., mostly thickly overlaid with gold. Mr. Davis will proceed with his excavations this winter with the assistance of Mr. Ayrton, who has left the Egypt Exploration Fund for this purpose.

\section{THE BEAUTY OF MINUTE} STRUCTURE IN NATURE.'

NE of the many ways of beginning the study of natural science is with a "beauty-feast"- of flowers or birds, of shells or gems, of anythingfor all natural things are beautiful, in their proper setting at least. It is an old-fashioned mode of approach, commending itself to children and simple minds, but one which often leads far beyond æsthetic pleasure to the joy of understanding. It affords a dynamic to investigation, and fosters a healthy reverence for things. In school " naturestudy" the æsthetic factor should be characteristic, though it is too often conspicuous by its absence. Indeed, if we had to choose, we should prefer admiration without science to science without admiration. But a simple book like that before us shows that there is no necessary antithesis; it is a disclosure of beautiful things, and yet within its limits it is quite scientific.

The author's aim is to illustrate by well chosen examples the beauty of minute structure, the beauty which the microscope discloses, and he is to be congratulated on his success. While older books on "the wonders of the microscope" had to be content with drawings, some of which were exquisitely done, this book presents us with photomicrographs of the highest excellence. It is difficult to over-praise them. Moreover, while the older books gave too much

1 "Nature through Microscope and Camera." By-Richard Kerr; with 65 photomicrographs by Arthur E. Smith. Pp. 197. (London: Religious Tract Society, rg05.) Price $6 s$. net.

No. 1883 , voL. 73$]$ prominence to curiosities and out-of-the-way objects, we are here brought into close quarters with the familiar, with diatoms and Foraminifera, the whelk's radula and the barnacle's cirri, the butterfly's "tongue " and the scales of the sole, the spine of the sea-urchin and the spider's foot, a gnat and a housefly's eggs, the dodder entering the clover, the bud of the lily flower, the sting of the nettle and the stem of wheat, and so on through a long list. Along with each of the sixty-five illustrations there is a short and clear description, and a note of the conditions of the photograph, e.g. magnification, focal distance, and exposure. The photographs were taken by $\mathrm{Mr}$. Arthur E. Smith, and are certainly among the finest that have ever been published. They were taken. for

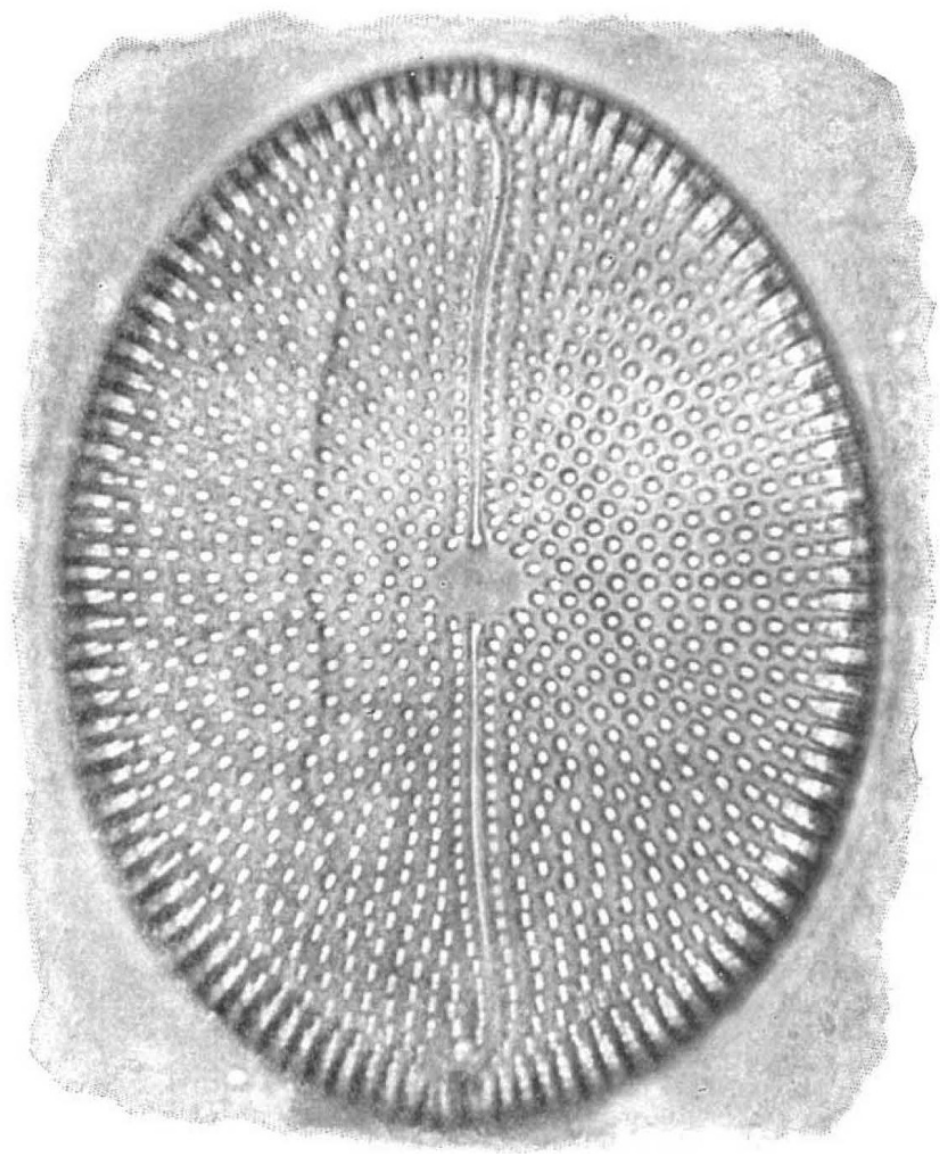
Fig. 1.-Diatom, from Bori, Hungary, $\times$ sooo. From "Nature through Microscope and the most part, on 12 by Io plates, and have been somewhat reduced in the process blocks. Mr. Smith contributes a useful chapter of practical hints on photomicrography.

Mr. Kerr is an enthusiastic photographer, who believes in his "intellectual pastime" as helping, indirectly, to "remedy some of the ills we are heir to, such as "the amusement fetich." But he is more, he is a student of the beautiful things which he delights in, and he can tell their story in a plain, straightforward way. The moral that adorns his tale is expounded by Prof. G. Sims Woodhead in a finely conceived introduction; but we shall only say this, that the whole spirit of this beautiful book is well 